\title{
Próba zginania doczołowych złączy spawanych - wymagania podstawowe i alternatywne
}

\section{Bend test of butt-weld joints - basic and optional requirements}

\section{Streszczenie}

W artykule podano sposoby wykonywania prób zginania doczołowych złączy spawanych. Przedstawiono rodzaje próbek, ich wymiary, sposób przygotowania do badań i kryteria doboru średnicy trzpienia gnącego. Na przykładzie badań własnych zilustrowano błędy wyników próby, związane z nieodpowiednim wyborem metody gięcia.
Abstract

The methods of bend test of butt-weld joints is presented in the paper. The types of specimen, their dimensions, preparation methods for testing and diameter of bend top punch selection criteria are discussed. On the basis of own test are considered the results errors according to unfit bend test method selection.

\section{Wstęp}

Próby zginania złączy spawanych należą do grupy badań właściwości mechanicznych, umożliwiających ocenę materiałów podstawowych i dodatkowych przeznaczonych na konstrukcje spawane. W konstrukcjach tych występuje trudność określenia możliwości zachowania się konstrukcji pod wpływem obciążeń rzeczywistych, z uwagi na niejednorodność połączeń pod wpływem metalurgicznym i chemicznym.

Próba zginania doczołowych złączy spawanych prowadzona jest w celu sprawdzenia plastyczności złączy oraz wykrycia ewentualnych niezgodności spawania lub zgrzewania. Prowadzi się ją na próbkach wyciętych ze złącza próbnego lub badanej konstrukcji. Z próbek usuwa się nadlewy spoiny równo z powierzchnią materiału rodzimego $\mathrm{w}$ ten sposób, aby rysy po próbce mechanicznej przebiegały zgodnie z kierunkiem naprężeń rozciągających w próbce podczas zginania. Niedopuszczalne jest usuwanie niezgodności zewnętrznych takich jak braki przetopu, wklęśnięcia lica czy podtopienia.

Norma PN-EN ISO 5173: 2010/A1: 2012 Badania nieniszczące spoin $\mathrm{w}$ materiałach metalowych.

Dr inż. Ryszard Pakos - Zachodniopomorski Uniwersytet Technologiczny w Szczecinie.
Badanie na zginanie - określa metodę badania zginania poprzecznego $z$ rozciąganiem od strony lica lub grani oraz zginania bocznego próbek do badania, pobranych ze spoin czołowych, spoin czołowych platerowanych (obejmujących spoiny płyt platerowanych i spoiny platerowane) i próbek platerowanych bez spoiny, w celu oceny ciągliwości (plastyczności) i/lub obecności niezgodności na powierzchni lub blisko powierzchni próbki do badania.

W normie tej przewidziano następujące rodzaje próbek:

- próbka do próby zginania poprzecznego z rozciąganiem od strony lica i grani spoiny czołowej (TFBB, TRBB),

- próbka poprzeczna do próby zginania bocznego złącza doczołowego (SBB),

- próbka do próby zginania wzdłużnego złącza doczołowego (LFBB, LRBB),

- próbka do zginania bocznego z platerem bez spoiny czołowej (SBC),

- próbka do zginania do czoła z platerem i ze spoiną czołową (FBCB),

- próbka do zginania bocznego z platerem i ze spoiną czołową (SBCB).

Kształt i wymiary próbek, sposób pobierania, znakowanie, przygotowanie powierzchni itp. podano na odpowiednich stronach normy [3]. 


\section{Próba zginania}

Próbki do badań należy wykonać w taki sposób, aby przygotowanie nie wpływało ani na materiał podstawowy, ani na spoinę. Końcowe etapy przygotowania powierzchni powinny być wykonane za pomoca obróbki skrawaniem, przy czym należy przestrzegać, by nie nastąpiło utwardzenie powierzchni przez zgniot lub jej nadmierne rozgrzewanie. Powierzchnia powinna być pozbawiona zarysowań i karbów poprzecznych do kierunku próbki, z wyjątkiem podtopień, których nie powinno się usuwać, jeżeli we właściwej normie wyrobu lub ustaleniach między stronami nie ustalono inaczej. Grubość próbek należy przyjmować zgodnie z wymaganiami normy [3].

Szerokość próbek określana jest następująco:

a) próba zginania poprzecznego z rozciąganiem od strony lica lub grani spoiny:

- dla blach: $\mathrm{b}=4$ xt (b-szerokość próbki, $\mathrm{t}$ - grubość próbki),

- dla rur o średnicy zewnętrznej $D \leq 50 \mathrm{~mm}$ : $\mathrm{b}=\mathrm{t}+0,1 \mathrm{D}$ (nie mniej niż $8 \mathrm{~mm}$ ),

- dla rur o średnicy zewnętrznej $D>50 \mathrm{~mm}$ : $\mathrm{b}=\mathrm{t}+0,5 \mathrm{D}(\min .8 \mathrm{~mm}$ i nie więcej niż $40 \mathrm{~mm}$ ),

w przypadku rur o średnicy większej niż 25 grubości jej ścianki próbkę można pobrać wg wymagań dla blach spełniające wymagania:

b) próba zginania bocznego:

- szerokość próbki powinna być równa grubości materiału podstawowego w pobliżu złącza,

c) próba zginania wzdłużnego:

szerokość próbek powinna wynosić:

- $B=L_{s}+2 b_{1}\left(L_{s}-\right.$ największa szerokość spoiny po obróbce, $b_{1}$ - odległość brzegu próbki od linii wtopienia)

Średnicę trzpienia gnącego określa się następująco:

- dla materiału podstawowego o wydłużeniu $A \geq 20 \%$

- $d=4 \times t$ ( $t$ - grubość próbki zginania),

- dla materiału podstawowego o wydłużeniu $A<20 \%$

$$
\mathrm{d}=\frac{100 \cdot \mathrm{t}}{\mathrm{A}}-\mathrm{t}[\mathrm{mm}]
$$

Spośród zalecanych metod gięcia stosowane są następujące próby:

A Próba zginania z zastosowaniem trzpienia gnącego (rys. 1 i 2 )

Próbę należy przeprowadzić, umieszczając próbkę na dwóch podporach utworzonych przez dwie równoległe rolki. Spoina powinna się znajdować w środku między rolkami podporowymi, z wyjątkiem próby zginania z użyciem próbek wzdłużnych. Próbki należy tak zginać, aby w środku rozpiętości obciążenie rosło stopniowo i w sposób ciągły, poprzez trzpień gnący $w$ osi spoiny prostopadle do powierzchni próbki.

B Próba zginania z zastosowaniem rolki zginającej (rys. 3)
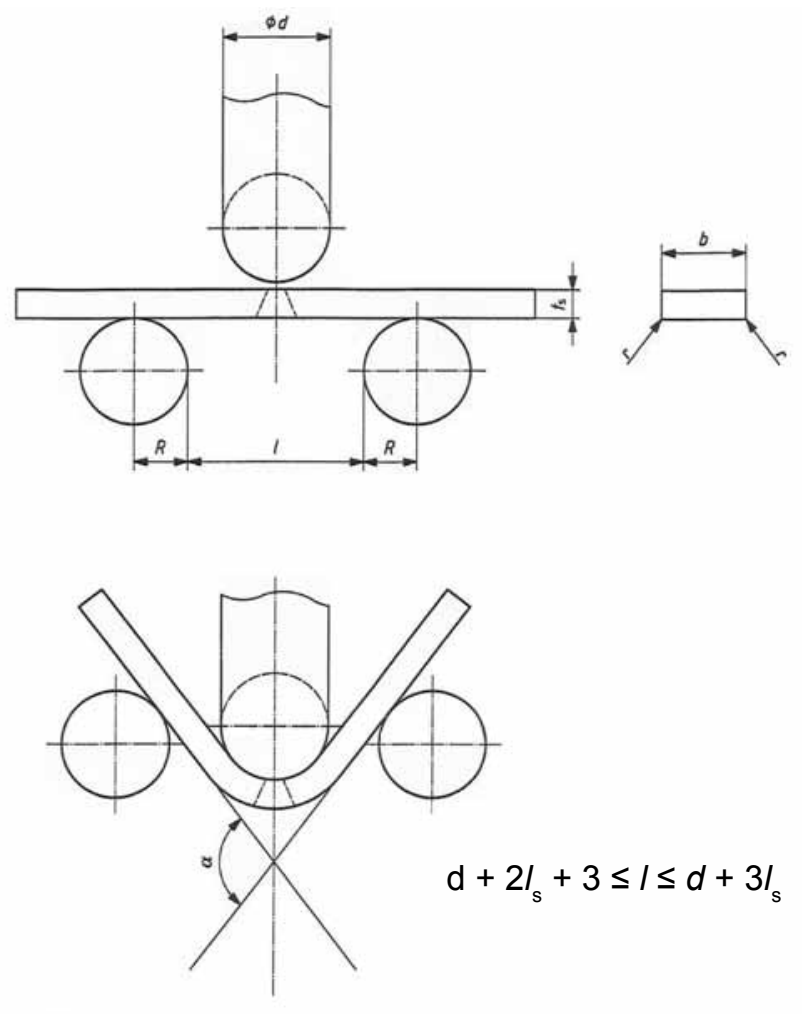

$d+2 t_{\mathrm{s}}+3 \leqslant l \leqslant d+3 t_{\mathrm{s}}$

Rys. 1. Metoda zginania $z$ trzpieniem gnącym. Zginanie z rozciąganiem od strony lica lub grani [3]

Fig. 1. The bend test with bend top punch. Bending with tension of face or root of weld [3]
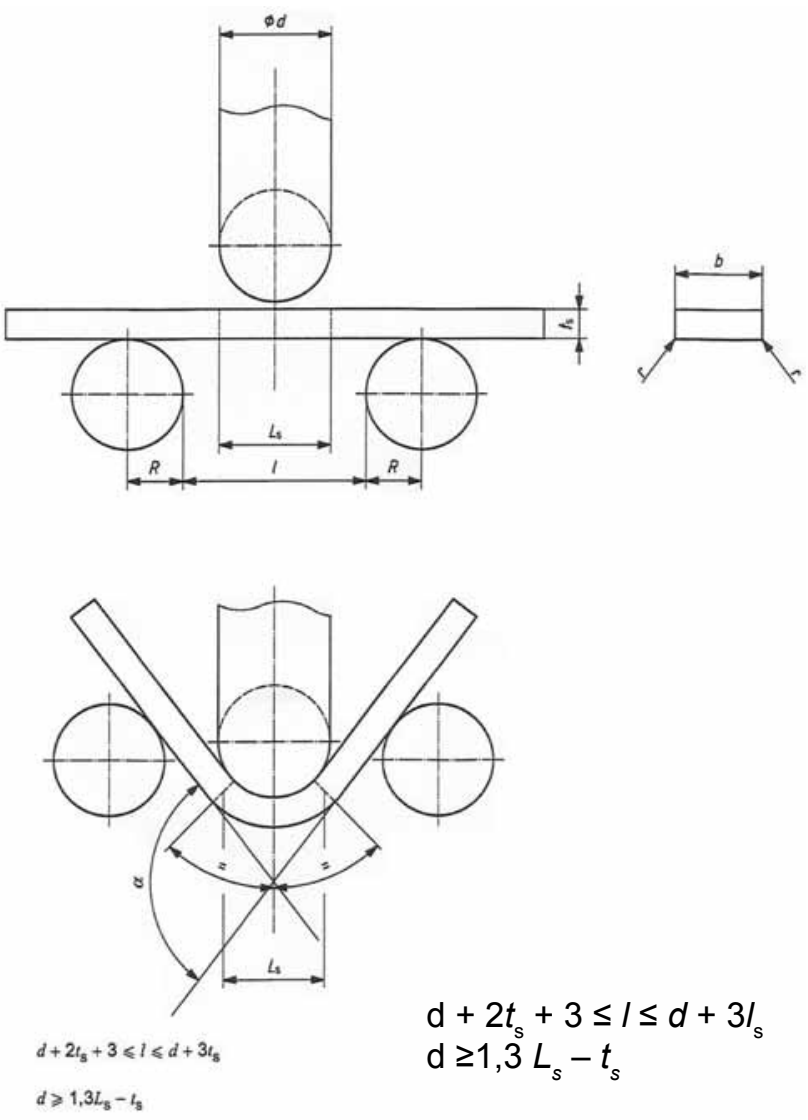

Rys. 2. Metoda zginania $z$ trzpieniem gnącym. Próba zginania bocznego [3]

Fig. 2. The bend test with bend top punch. Side bend test [3] 


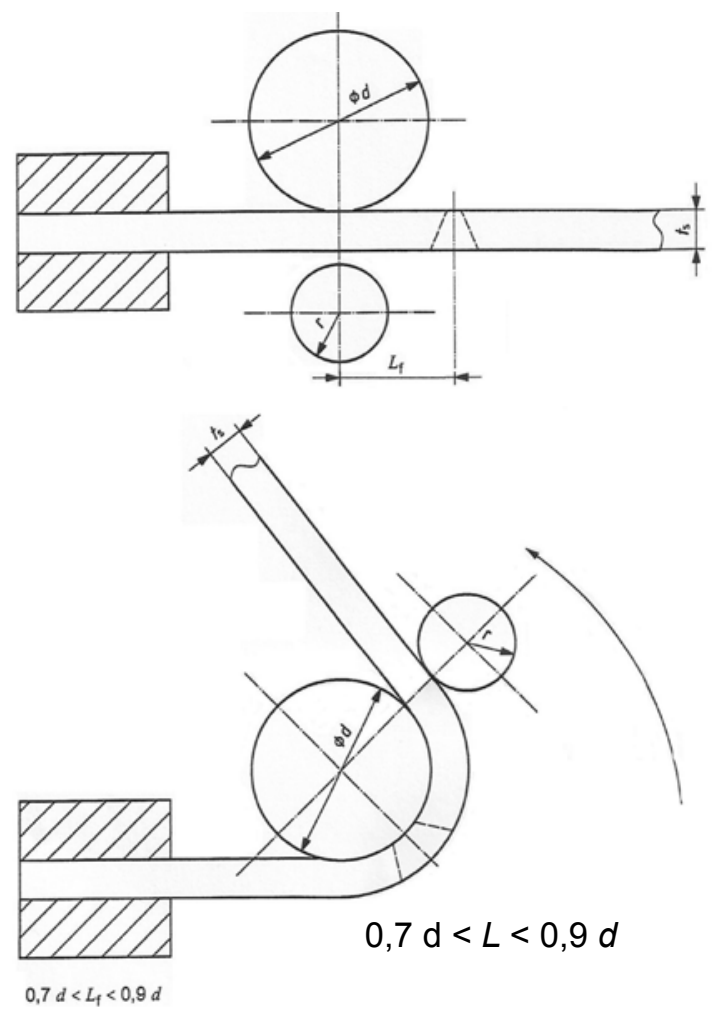

Rys. 3. Metoda zginania z rolką zginającą [3] Fig. 3. The bend test with bending roller [3]

Próba jest alternatywną metodą stosowaną do próbek ze stopów aluminium i innych materiałów, gdy spoina lub jeden z łączonych materiałów ma niższą umowną lub wyraźną granicę plastyczności.

\section{Badania własne}

Celem badań było wykonanie próby zginania poprzecznego na próbkach pobranych ze złączy spawanych doczołowych wykonanych z blach o wysokiej wytrzymałości, gdzie spoina ma niższą granicę plastyczności niż materiał podstawowy. Badania dwoma metodami, tj.: metodą zginania poprzecznego $z$ trzpieniem gnącym i z zastosowaniem rolki zginającej.

\section{Dane wejściowe:}

- materiał spawany: stal o wysokiej wytrzymałości $\mathrm{S} 1100 \mathrm{QL}$ i grubości $\mathrm{g}=10 \mathrm{~mm}, \mathrm{R}_{\text {emin }}=1192 \mathrm{MPa}$,

- materiał dodatkowy: drut spawalniczy UNION NiMoCr (GMn4Ni1,5CrMo), $\mathrm{R}_{\text {emin }}=720 \mathrm{MPa}$,

- metoda spawania 135 (pozycja PA),

- średnica trzpienia gnącego: $90 \mathrm{~mm}$.

Badania metodą zginania poprzecznego z trzpieniem gnącym wykonano na maszynie wytrzymałościowej INSTRON $5585 \mathrm{H}$ (rys. 4), natomiast próbę zginania z zastosowaniem rolki zginającej przeprowadzono na prototypowym przyrządzie dostosowanym do wymagań próby (rys. 5).

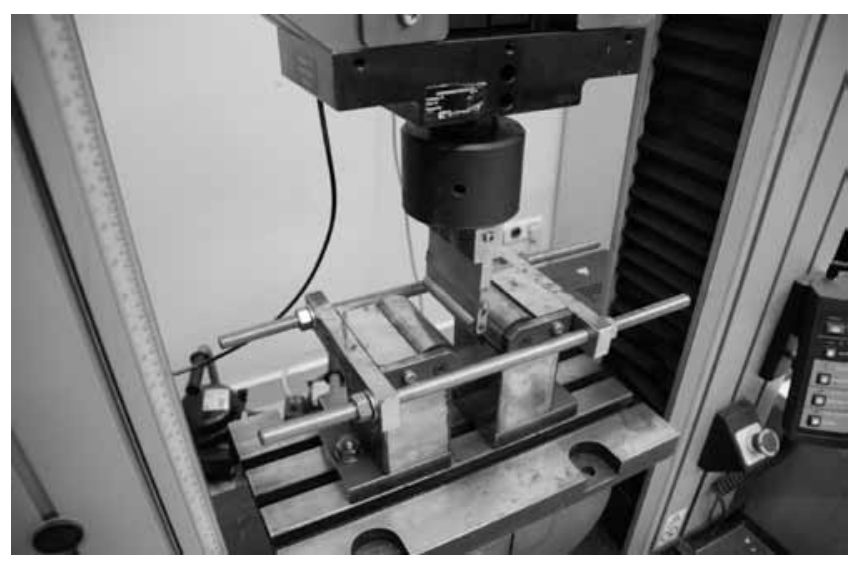

Rys. 4. Stanowisko do gięcia z trzpieniem gnącym

Fig. 4. Testing station for bending with top punch

Podczas próby gięcia z trzpieniem gnącym zauważono, że próbka pomimo założenia trzpienia o średnicy $90 \mathrm{~mm}$ ginała się tak, jakby gięto ją na trzpieniu o średnicy ok. 25 mm (rys. 6 - górna próbka). W wyniku tej próby nastąpiło pęknięcie próbki przy bardzo małym kącie zginania - stąd niezaliczenie próby.

W przypadku zginania z zastosowaniem rolki zginającej uzyskano zadowalający wynik próby, przy jej łagodnym przebiegu (rys. 6 - dolna próbka).

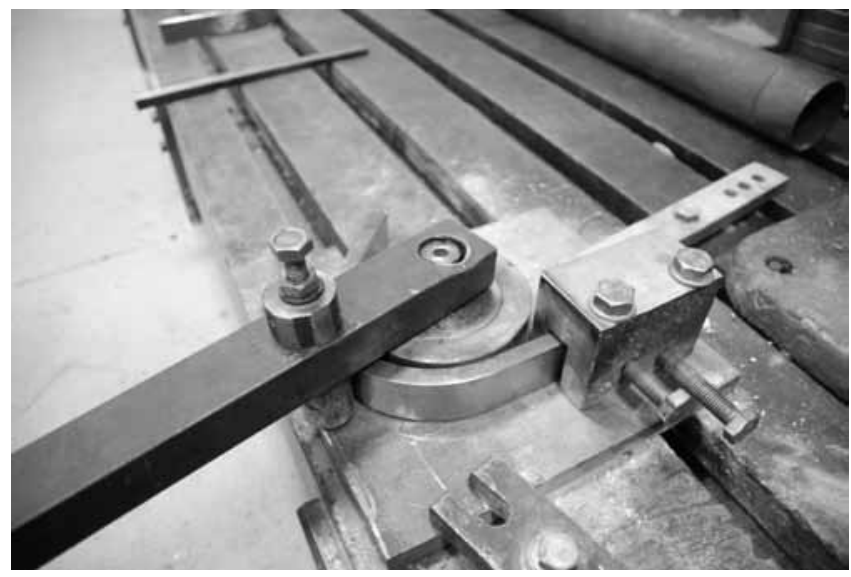

Rys. 5. Stanowisko do gięcia z rolką zginającą

Fig. 5. Testing station for bending with bending roller

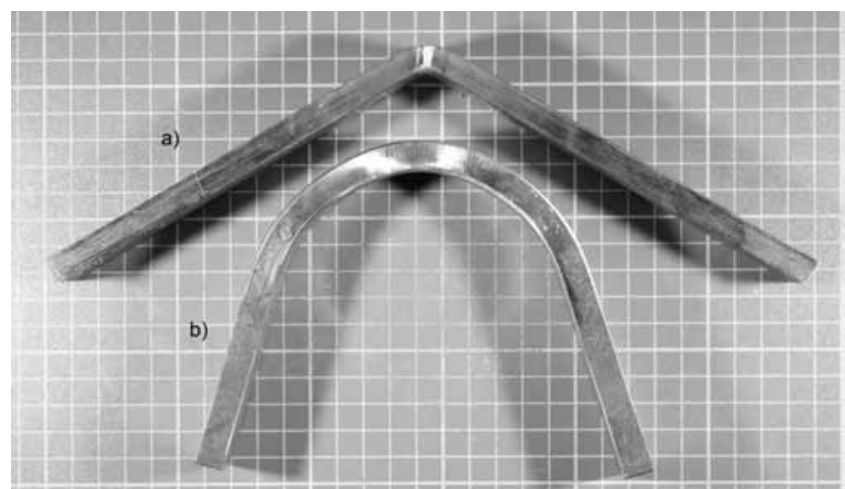

Rys. 6. Próbki po gięciu: a) z trzpieniem gnącym, b) z rolką zginającą Fig. 6. Specimens after bending test: a) with top punch, b) with bending roller 


\section{Podsumowanie}

Próba zginania doczołowych złączy spawanych należy do najprostszej grupy badań właściwości mechanicznych. Należy jednak pamiętać, że o powodzeniu próby i tym samym jej uwzględnieniu decyduje kilka bardzo ważnych zaleceń, do których należy zaliczyć m.in.:

- dokładne przygotowanie próbek, spełniających zalecenia normy;

- dobór odpowiedniej średnicy trzpienia gnącego, wynikającego z właściwości plastycznych materiału, ponieważ zbyt mała średnica trzpienia gnącego sprawia, że próba jest zbyt „ostra” i wyniki jej nie odzwierciedlają w pełni rzeczywistych właściwości plastycznych badanego złącza;

- zastosowanie właściwej metody gięcia, przy czym szczególną uwagę należy zachować przy gięciu połączeń spawanych $z$ aluminium i jego stopów oraz materiałów, gdzie występują istotne różnice granicy plastyczności materiału podstawowego i dodatkowego.

\section{Literatura}

[1] Czuchryj J., Kurpisz B.: Badanie złączy spawanych. Przegląd metod. Wydawnictwo Kabe. Krosno 2009.

[2] Pilarczyk J.: Poradnik inżyniera. Spawalnictwo t.1. WTN. Warszawa 2003
[3] PN-EN ISO 5173: 2010. Badania niszczące spoin w materiałach metalowych - Badania na zginanie.

[4] PN-EN ISO 15614-1: 2004. Specyfika i kwalifikowanie technologii spawania metali. Badanie technologii spawania. Część 1: Spawanie łukowe i gazowe stali oraz spawanie łukowe niklu i stopów niklu.

\section{Dolnośląska Sekcja Spawalnicza SIMP Zakład Spawalnictwa Instytutu Technologii Maszyn i Automatyzacji i Wydział Mechaniczny Politechniki Wrocławskiej}

\section{w 4. Międzynarodowej Konferencji Naukowo - Technicznej pod hasłem „POSTĘP W TECHNOLOGIACH LUTOWANIA” WROCKAW 2013}

zapraszają do udziału

Wrocław, 23-25 września 2013 (poniedziałek - środa) aula A1, bud. B-4 PWr, ul. tukasiewicza 5

Wszystkich zainteresowanych udziałem w Konferencji prosimy o kontakt z Zakładem Spawalnictwa ITMiA Politechniki Wrocławskiej

Prof. dr hab. inż. dr h.c. Władysław Włosiński - Przewodniczący Komitetu Naukowego IV Wydzial Nauk Technicznych PAN Warszawa

Prof. dr hab. inż. Andrzej Ambroziak - Sekretarz Komitetu Naukowego tel. (071) 3202148, e-mail: andrzej.ambroziak@pwr.wroc.pl

Prof. dr hab. inż. Zbigniew Mirski - Przewodniczący Komitetu Organizacyjnego tel. (071) 3202142, e-mail: zbigniew.mirski@pwr.wroc.pl

Mgr inż. Anna Woźna - Sekretarz Komitetu Organizacyjnego tel. (071) 3202074, e-mail: anna.wozna@pwr.wroc.pl Dr inż. Tomasz Piwowarczyk - Sekretarz Komitetu Organizacyjnego tel. (071) 3204255, e-mail: tomasz.piwowarczyk@pwr.wroc.pl

Korespondencję prosimy kierować na adres:

Komitet Organizacyjny 4. Międzynarodowej Konferencji Naukowo - Technicznej "Postęp w technologiach lutowania"

Politechnika Wrocławska, Zakład Spawalnictwa ITMiA

Wybrzeże Wyspiańskiego 27 50-370 Wrocław 